\title{
Impact of tropical cyclone Amang on variability of wind speed, salinity, sea surface temperature, and their relationship to chlorophyll-a in sea waters of Sangihe Island
}

\author{
Indonesian title: \\ Dampak siklon tropis Amang terhadap variabilitas kecepatan angin, salinitas, suhu permukaan \\ laut, dan hubungannya dengan klorofil- $a$ di perairan laut Pulau Sangihe
}

\author{
M. Hatta Rachim ${ }^{1,3 *}$, Joshian N.W. Schaduw ${ }^{2}$, Adnan S. Wantasen², Wilhelmina Patty ${ }^{2}$, \\ Edwin L.A. Ngangi ${ }^{2}$ \\ ${ }^{I}$ Program Studi Magister Ilmu Perairan, Fakultas Perikanan dan Ilmu Kelautan, Universitas Sam Ratulangi \\ Jl. Kampus Unsrat Bahu, Manado 95115 Sulawesi Utara, Indonesia \\ ${ }^{2}$ Fakultas Perikanan dan Ilmu Kelautan, Universitas Sam Ratulangi, Jl. Kampus Unsrat Bahu, \\ Manado 95115, Sulawesi Utara, Indonesia \\ ${ }^{3}$ Stasiun Meteorologi Sam Ratulangi Manad (BMKG), Jl. A.A. Maramis, Manado, Sulawesi Utara, Indonesia \\ *Corresponding author: atha.funter@gmail.com
}

Received: 5 July 2021 - Revised: 3 August 2021 -Accepted: 7 August 2021

\begin{abstract}
High concentrations of chlorophyll-a can be used to predict where fish gather. On the other hand, tropical cyclones are one of the triggering factors for vertical stirring and upwelling that cause fertility of waters. The Sangihe Island area is not an effective area for the formation of tropical cyclones. However, due to its geographical location with a tropical cyclone area and trajectory, the potential for disturbances caused by cyclones is impactful on Sangihe Island. The distribution of wind speed, salinity, sea surface temperature and chlorophyll-a concentration can be detected by satellite remote sensing imagery. This study aims to analyze the impact of Tropical Cyclone Amang on the variability of wind speed, salinity, sea surface temperature and on the concentration of chlorophyll-a in Sangihe Island. This study uses wind speed, salinity, sea surface temperature and chlorophyll-a data during the Amang Tropical Cyclone (January 6-27, 2019) from the AQUA-MODIS satellite imagery. The results show that the relationship between wind speed and chlorophyll-a concentration has impact on other parameters where both parameters showed a strong correlation value. It was also showed on the relationship between sea surface temperature and chlorophyll-a. However, the relationship between salinity and chlorophyll-a concentration showed lowest effect among those parameters.
\end{abstract}

Keywords: wind speed; salinity; sea surface temperature; chlorofil-a; tropical cyclone

\section{PENDAHULUAN}

Indikator kesuburan suatu perairan dapat ditentukan dari jumlah konsentrasi klorofil- $a$ dalam fitoplankton. Distribusi konsentrasi klorofil- $a$ yang tinggi dapat digunakan sebagai indikator untuk menduga tempat berkumpulnya ikan, karena klorofil- $a$ berada pada rantai makanan awal dalam ekosistem lautan (Tangke et al., 2015). Klorofil- $a$ merupakan komponen penting sebagai sumber makanan alami bagi ikan (Hatta, 2002).
Siklon tropis menjadi salah satu faktor pemicu terjadinya pengadukan vertikal dan upwelling, yang menyebabkan meningkatnya kesuburan perairan. Siklon ini merupakan bentuk gangguan cuaca ekstrim, yang diawali dengan munculnya pusat tekanan rendah di atas lautan yang luas dengan radius dampak mencapai 150-200 km (Zakir, 2006). Karena dampaknya yang sangat luas, siklon ini dapat memengaruhi varibilitas parameter oseanografi di wilayah tersebut.

Wilayah Pulau Sangihe bukan merupakan wilayah yang cukup efektif bagi terbentuknya siklon 
tropis. Tetapi, karena posisi geografisnya yang berbatasan dengan wilayah pembentukan maupun area lintasan siklon ini, maka potensi gangguan yang disebabkan oleh siklon ini sangat besar terjadi di wilayah tersebut. Menurut Wang et al. (2009), siklon tropis dapat memicu terbentuknya eddy (pusaran) perubahan kedalaman lapisan termoklin dan pergerakan vertikal massa air yang kaya akan nutrien ke lapisan permukaan. Sebagai contoh, siklon tropis Nuri mampu meningkatkan konsentrasi klorofil- $a 5$ kali lebih tinggi dari tingkat normal pada hari ke-2 terjadinya dan berlangsung selama sekitar seminggu (Ye et al., 2013).

Kecepatan angin, salinitas, suhu permukaan laut (SPL), dan distribusi konsentrasi klorofil- $a$ dapat dideteksi dengan menggunakan data pengideraan jauh menggunakan satelit. Citra penginderaan jauh MODIS dari satelit Aqua/Terra dapat dimanfaatkan untuk pemantauan dan kajian SPL dan konsentrasi klorofil- $a$, karena mempunyai band termal dan resolusi temporal yang tinggi sehingga dinamika perubahan SPL dapat diamati secara kontinu (Ayu et al., 2011).

Penelitian ini bertujuan untuk mengetahui dampak siklon tropis Amang terhadap kelimpahan klorofil- $a$, menganilisis variabilitas kecepatan angin, salinitas, SPL dan menganalisis hubungannya dengan kelimpahan klorofil- $a$ di perairan laut Pulau Sangihe. Melalui penelitian ini, dapat diperoleh informasi mengenai dampak siklon tropis apabila terjadi kejadian serupa di lokasi yang sama maupun di lokasi lain.

\section{MATERIAL DAN METODE}

\section{Waktu dan Lokasi Peneltian}

Wilayah yang diamati dalam penelitian ini, yaitu perairan Pulau Sangihe pada posisi koordinat $3,5^{\circ}-4,5^{\circ} \mathrm{LU}$ dan $125^{\circ}-126^{\circ}$ BT (Gambar 1). Periode data yang digunakan, yaitu periode sebelum, saat, dan setelah terjadinya siklon tropis Amang, yaitu tanggal 6-27 Januari 2019.

\section{Jenis dan Teknik Pengambilan Data}

Jenis data yang dikumpulkan dalam penelitian, yaitu 1) data penginderaan jauh Citra AQUA-MODIS level 4 dengan resolusi $0,25^{\circ} \times 0,25^{\circ}$ komposit harian untuk parameter kecepatan angin, salinitas, dan SPL, periode Januari 2019, 2) data penginderaan jauh Citra AQUA-MODIS level 4 dengan resolusi $0,25^{\circ} \times 0,25^{\circ}$ komposit harian untuk parameter klorofil- $a$, periode Januari 2015-2019. Data dikumpukan dengan cara diunduh dalam format .nc melalui website NOAA (https://coastwatch.pfeg. noaa.gov/).

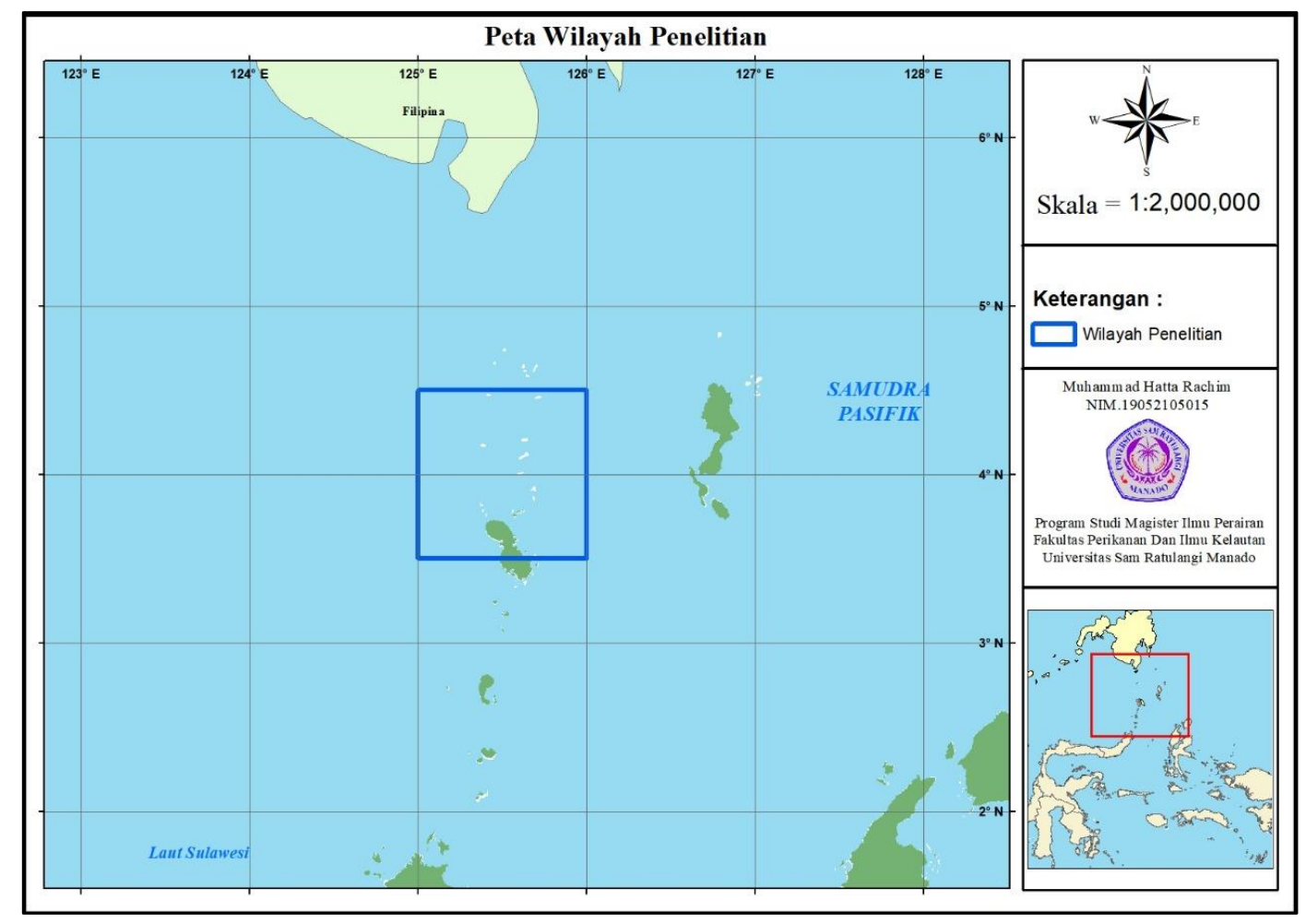

Gambar 1. Peta wilayah penelitian di perairan Pulau Sangihe, Sulawesi Utara 


\section{Analisis Data}

Data kecepatan angin, salinitas, SPL, dan klorofil- $a$ dari hasil pencitraan penginderaan jauh MODIS dan ASCAT dianalisis. Pengolahan data dalam bentuk sebaran spasial dan temporal dari parameter di atas dilakukan dengan bantuan perangkat lunak GrADS (the Grid Analysis and Display System), yang menghasilkan data numerik dalam format '.xls'. Kemudian, data dalam format '.nc' diolah ke dalam bentuk format '.jpg' untuk menghasilkan peta sebaran untuk masing-masing parameter.

Selanjutnya, dilakukan proses perhitungan secara matematis untuk menentukan nilai korelasi dan regresi untuk masing-masing parameter. Kuattidaknya suatu korelasi diukur dengan suatu nilai yang disebut koefisien korelasi (Sugiyono, 2010). Koefisien korelasi yang digunakan, yaitu koefisien korelasi Pearson. Data dianalisis menurut waktu kejadian, yaitu sebelum, saat, dan setelah terjadinya siklon tropis Amang. Hubungan yang terjadi antara kecepatan angin, salinitas, SPL, dan konsentrasi klorofil- $a$ pada sebelum, saat, dan setelah terjadinya siklon tropis Amang dianalisis.

Pendugaan kekuatan hubungan konsentrasi antara kecepatan angin, salinitas, dan SPL terhadap klorofil- $a$ dilakukan dengan perhitungan koefisien korelasi $(r)$. Nilai korelasi dapat dihitung dengan menggunakan rumus:

$$
\operatorname{rxy}=\frac{n \sum x y-\sum x \sum y}{\sqrt{\left(n \sum x^{2}-\left(\sum x\right)^{2}\right)\left(n \sum y^{2}-\left(\sum x\right)^{2}\right)}}
$$

di mana $n$ : banyaknya pasangan data kecepatan angin, salinitas, SPL dan klorofil- $a$; $\Sigma \mathrm{x}$ : total jumlah dari variabel $x ; \Sigma$ y: total jumlah dari variabel $y ; \Sigma \mathrm{x}^{2}$ : kuadrat dari total jumlah variabel $x ; \Sigma \mathrm{y}^{2}:$ kuadrat dari total jumlah variabel $y ; \Sigma x y$ : hasil perkalian dari total jumlah variabel $x$ dan $y ; x$ : variabel $x$ (kecepatan angin, salinitas, dan SPL); y: variabel $y$ (klorofil- $a$ ). Nilai koefisien korelasi hasil perhitungan dari persamaan di atas kemudian dibagi menjadi 7 kelas dan dapat diinterpretasi (Tabel 1).

Menurut Ghozali (2006), koefisien penentu (KP) atau koefisien determinasi (R), yang merupakan penyebab perubahan pada variabel terikat yang datang dari variabel bebas, adalah sebesar kuadrat koefisien korelasinya. Koefisien penentu ini menjelaskan besarnya pengaruh nilai suatu variabel (variabel bebas) terhadap variasi nilai variabel lainnya (variabel terikat); dirumuskan sebagai berikut: $\mathrm{KP}=\mathrm{R}=\left(\mathrm{r}_{\mathrm{xy}}\right)^{2} \times 100$, di mana $\mathrm{KP}$ atau R: koefisien penentu; rxy: koefisien korelasi.

\section{HASIL DAN PEMBAHASAN}

Hasil analisis menunjukkan, kecepatan angin sebelum terjadinya siklon tropis Amang lebih lemah jika dibandingkan dengan pada saat terjadinya, dan kecepatan angin semakin kuat bahkan semakin masuk ke wilayah perairan Pulau Sangihe. Besar kecepatan angin sebelum terjadinya siklon tersebut adalah berkisar 6-9 m/s; sedangkan pada saat terjadi siklon, kecepatannya berkisar 7-11 m/s. Kecepatan angin mengalami peningkatan hingga $5 \mathrm{~m} / \mathrm{s}$.

Peningkatan kecepatan angin yang diukur sejalan dengan pendapat Zakir (2010), yang menemukan, kecepatan angin pada fase depresi tropis ke fase siklon tropis mengalami peningkatan kecepatan hingga $15 \mathrm{~m} / \mathrm{s}$. Bernawis (2000) menyatakan, siklon tropis dapat memicu terjadinya peningkatan pada kondisi kecepatan angin yang tinggi dan pergerakan arus yang lambat. Pada umumnya kecepatan angin yang tinggi justru terjadi pada daerah yang berjarak 20-30 mil dari pusat siklon.

Kecepatan angin setelah terjadinya siklon tropis Amang lebih lemah dibandingkan dengan saat terjadinya siklon. Kecepatan angin setelah terjadinya siklon berkisar antara 6-9 m/s. Kecepatan angin mengalami penurunan hingga $8 \mathrm{~m} / \mathrm{s}$. Hasil ini menunjukkan, bahwa siklon tropis Amang memengaruhi peningkatan kecepatan angin di wilayah perairan laut Pulau Sangihe.

Keadaan salinitas sebelum, saat, dan setelah terjadinya siklon tropis Amang tidak terpantau adanya perubahan yang signifikan. Walaupun demikian, nilai salinitas (34,0-34,2 ppt) mengalami peningkatan pada saat terjadinya siklon, namun kenaikannya tidak signifikan dari kondisi sebelum dan setelah terjadinya siklon tersebut. Hasil ini menunjukkan, bahwa siklon tropis Amang tidak memengaruhi keadaan salinitas di perairan laut Pulau Sangihe.

Keadaan SPL pada saat terjadinya siklon tropis Amang lebih rendah jika dibandingkan dengan SPL sebelum dan setelah terjadinya siklon. Suhu permukaan laut (SPL) pada saat terjadinya siklon berkisar 27,4-27,8 ${ }^{\circ} \mathrm{C}$; sedangkan SPL sebelum dan setelah terjadinya siklon berkisar $27,5-28,6{ }^{\circ} \mathrm{C}$. Suhu permukaan laut (SPL) pada saat terjadinya siklon mengalami penurunan hingga $1,2{ }^{\circ} \mathrm{C}$. Hal ini sependapat dengan Gaol et al. (2018), bahwa SPL menunjukkan penurunan dengan nilai tertinggi mencapai $2,5^{\circ} \mathrm{C}$ dalam kurun waktu 1-4 hari setelah terbentuknya siklon tropis.

Kejadian tersebut di atas juga dipengaruhi oleh kondisi cuaca pada saat terjadinya siklon tropis di mana berpeluang terjadi hujan dengan intensitas 
Rachim et al.: Impact of tropical cyclone Amang on variability of wind speed, salinity, ...

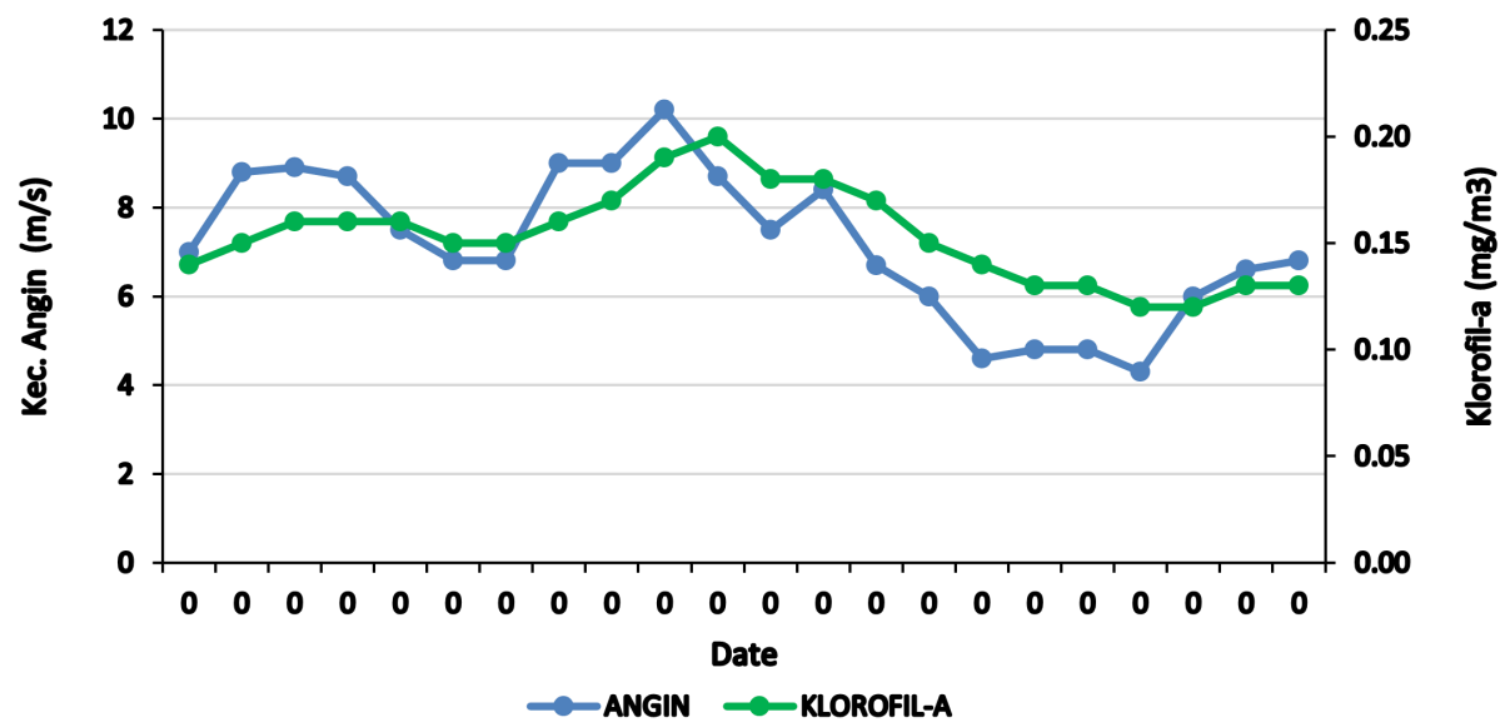

Gambar 2. Grafik korelasi kecepatan angin dengan klorofil- $a$

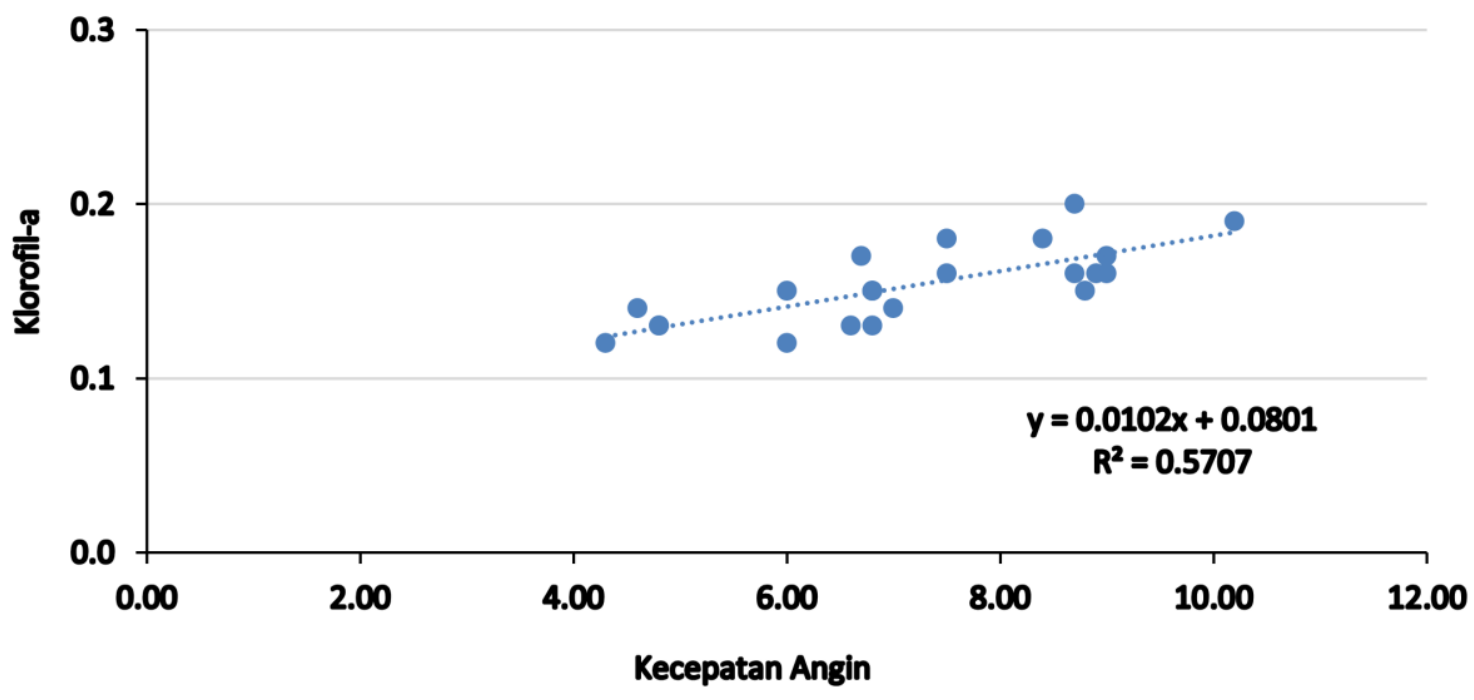

Gambar 3. Grafik regresi kecepatan angin dengan klorofil- $a$

sedang hingga lebat sehingga mengindikasikan SPL lebih rendah dibandingkan pada saat sebelum dan setelah terjadinya siklon tropis. Hasil ini menunjukkan, bahwa siklon tropis Amang memengaruhi penurunan SPL di wilayah perairan Pulau Sangihe.

Konsentrasi klorofil- $a$, pada saat terjadinya siklon tropis Amang, mengalami kenaikan jika dibandingkan dengan sebelum dan setelah terjadinya siklon. Kandungan klorofil- $a$ pada saat terjadinya siklon berkisar $0,16-0,20 \mathrm{mg} / \mathrm{m}^{3}$. Konsentrasi klorofil- $a$ mengalami kenaikan sebesar $0,06 \mathrm{mg} / \mathrm{m}^{3}$ $(30 \%)$ jika dibandingkan dengan sebelum terjadinya siklon tropis.

Hal ini sependapat dengan Ye et al. (2013), yang menyatakan, bahwa siklon tropis Nuri mampu meningkatkan konsentrasi klorofil-a 5 kali lebih tinggi dari tingkat normal pada hari ke-2 dan berlangsung sekitar satu minggu serta menginduksi pencampuran vertikal secara signifikan. Siadari et al. (2017) juga menyatakan, bahwa siklon tropis Frances meningkatkan konsentrasi klorofil- $a$ di Laut Timor berkisar $0,4-5,0 \mathrm{mg} / \mathrm{m}^{3}$.

Setelah terjadinya siklon tropis Amang konsentrasi klorofil- $a$ kembali berkurang jika dibandingkan dengan pada saat terjadinya siklon. Konsentrasi klorofil- $a$ setelah terjadi siklon berkisar $0,12-0,14 \mathrm{mg} / \mathrm{m}^{3}$ (40\%). Hasil ini menunjukkan, bahwa siklon tropis Amang memengaruhi kenaikan konsentrasi klorofil- $a$ di wilayah perairan laut Pulau Sangihe. 


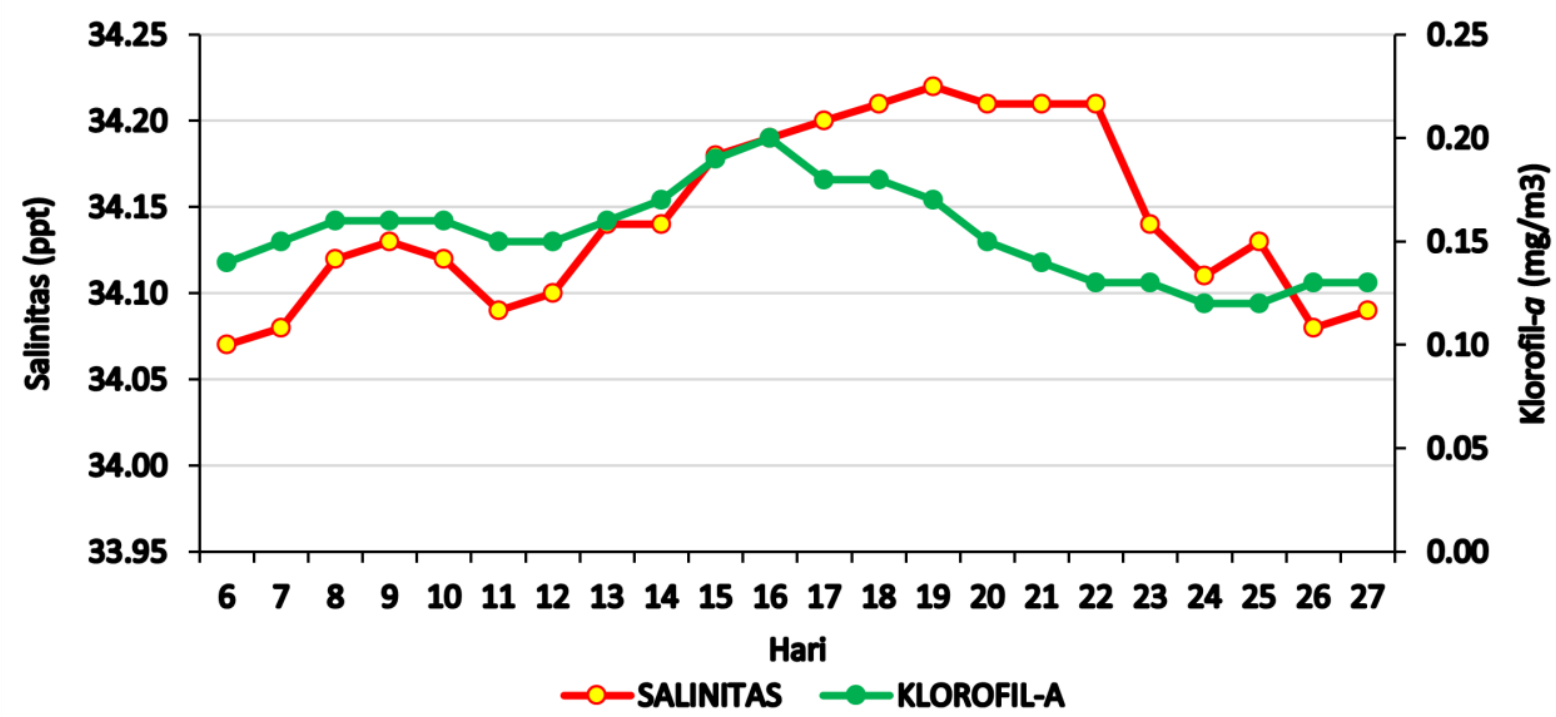

Gambar 4. Grafik korelasi salinitas dengan klorofil- $a$

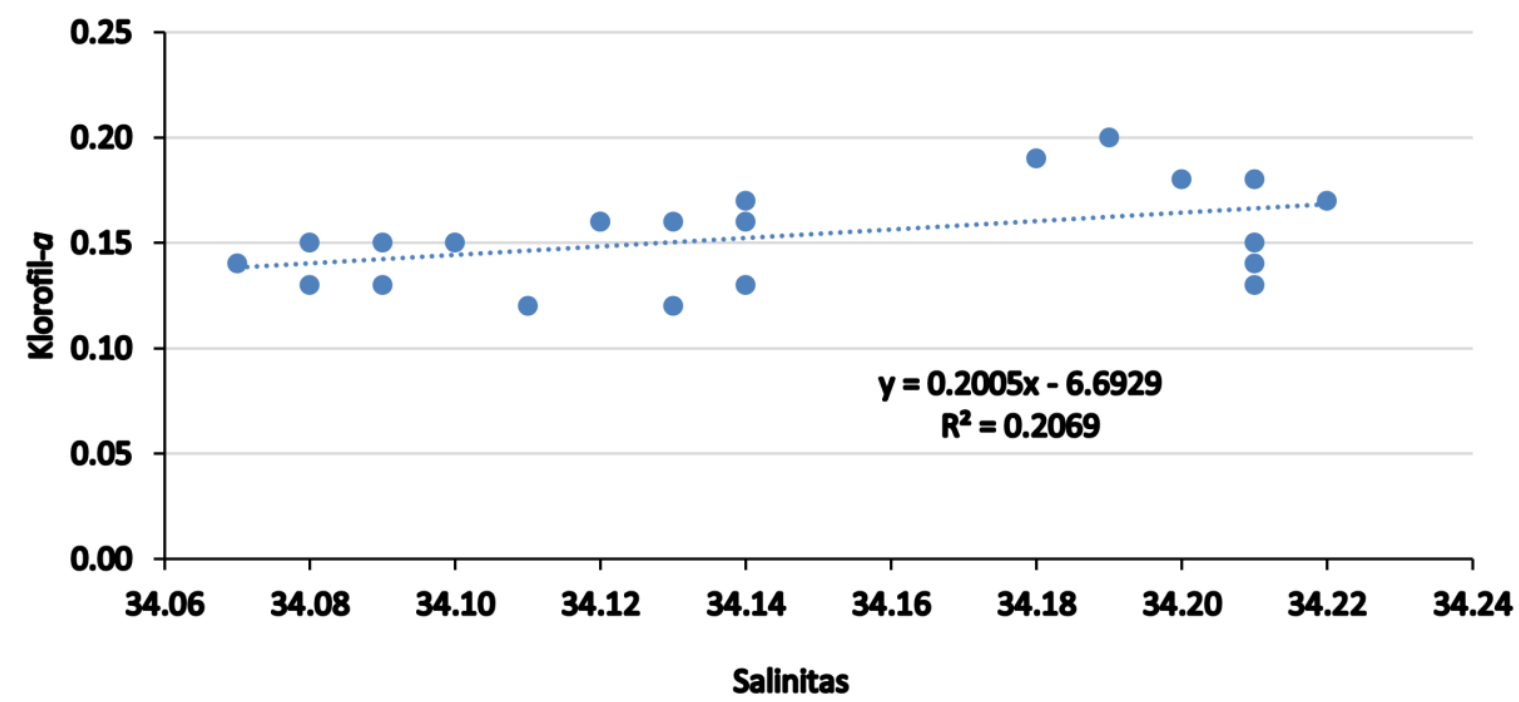

Gambar 5. Grafik regresi salinitas dengan klorofil- $a$

\section{Hubungan Kecepatan Angin dengan Klorofil- $a$}

Hasil analisis menunjukkan adanya nilai korelasi positif kuat $(r=0,76)$ antara kecepatan angin dan konsentrasi klorofil- $a$. Nilai korelasi (r) tersebut berbanding lurus, yang artinya bahwa pada saat kecepatan angin menguat maka konsentrasi klorofil$a$ meningkat, demikian pula sebaliknya. Korelasi tersebut sesuai dengan pernyataan Zakir (2010), bahwa kecepatan angin pada fase depresi tropis ke fase siklon tropis mengalami peningkatan kecepatan angin hingga $15 \mathrm{~m} / \mathrm{s}$. Bernawis (2000) juga menyatakan, bahwa siklon tropis dapat memicu terjadinya peningkatan pada kondisi kecepatan angin yang tinggi dan pergerakan arus yang lambat. Pada umumnya kecepatan angin yang tinggi justru terjadi pada daerah yang berjarak 20-30 mil dari pusat siklon (Gambar 2).
Nilai koefisien $\mathrm{R}^{2}$ antara besarnya pengaruh kecepatan angin dan naik turunnya konsentrasi klorofil- $a$ mencapai 0,5707 (57\%). Dari nilai determinasi ini diketahui kecepatan angin memengaruhi konsentrasi klorofil- $a$ cukup besar, yaitu sebesar 57\%. Sedangkan sisanya (43\%) dipengaruhi oleh faktor lain. Hal ini sesuai dengan pernyataan Zakir (2010) dan Bernawis (2000). Gaol et al. (2018) menyatakan, bahwa siklon tropis Frances memengaruhi kecepatan angin hingga 24-28 knot dan berangsur melemah menjadi 8-20 knot beberapa hari kemudian hingga siklon tropis punah (Gambar 3).

\section{Hubungan Salinitas dengan Klorofil- $a$}

Hasil analisis menunjukkan adanya korelasi positif tingkat sedang antara salinitas dengan 
Rachim et al.: Impact of tropical cyclone Amang on variability of wind speed, salinity, ...

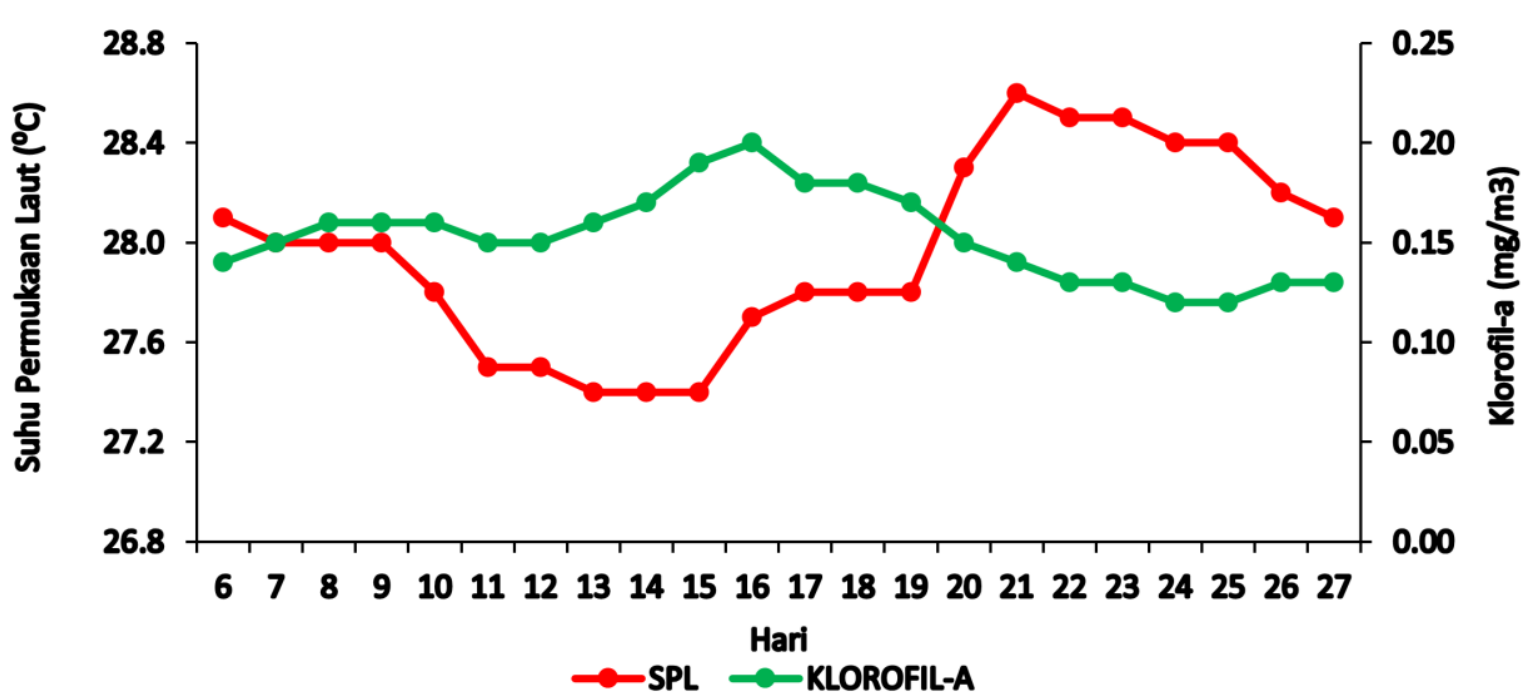

Gambar 6. Grafik korelasi suhu permukaan laut (SPL) dengan klorofil- $a$

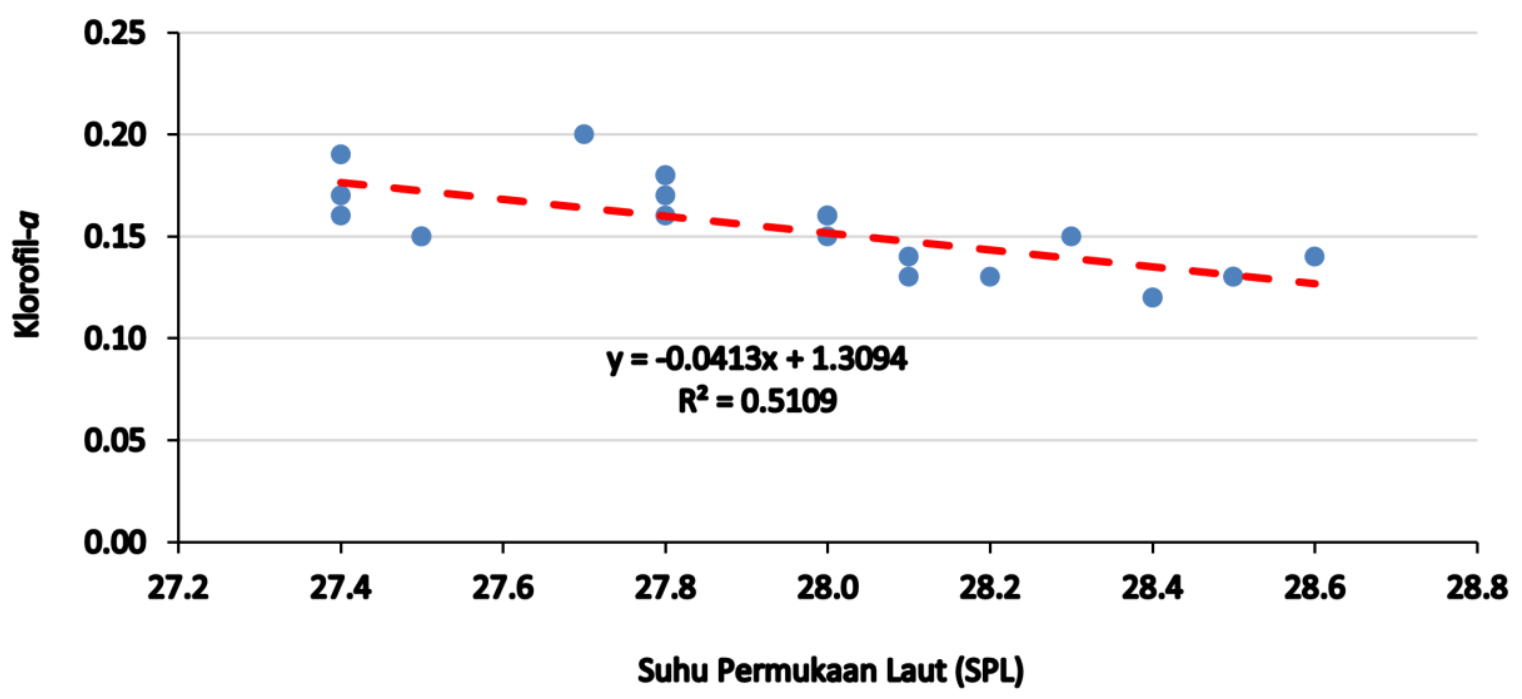

Gambar 7. Grafik regresi suhu permukaan laut (SPL) dengan klorofil- $a$

konsentrasi klorofil- $a(\mathrm{r}=0,45)$. Hubungan keduanya berbanding lurus di mana pada saat kondisi salinitas meningkat, konsentrasi klorofil-a juga meningkat; demikian pula sebaliknya (Gambar 4). Nilai koefisien $\mathrm{R}^{2}$ antara besarnya pengaruh salinitas dan naik turunnya konsentrasi klorofil- $a$ mencapai 0,2069 (20\%). Dari nilai determinasi ini diketahui bahwa salinitas memengaruhi konsentrasi klorofil- $a$ cukup besar, yaitu sebesar 20\%. Sedangkan sisanya (80\%) dipengaruhi faktor lain (Gambar 5).

\section{Hubungan Suhu Permukaan Laut (SPL) dengan Klorofil- $a$}

Hasil analisis korelasi antara SPL dan klorofil$a$ menunjukkan adanya korelasi negatif kuat ( $\mathrm{r}=$ $-0,71)$. Hubungan keduanya berbanding terbalik di mana pada saat kondisi SPL menurun, maka konsentrasi klorofil-a meningkat; demikian sebaliknya. Hasil korelasi ini sesuai dengan pernyataan Ye et al. (2013), bahwa siklon tropis Nuri mampu meningkatkan konsentrasi klorofil- $a 5$ kali lebih tinggi dari tingkat normal pada hari ke-2 dan berlangsung selama sekitar satu minggu, serta menginduksi pencampuran vertikal secara signifikan. Siadari et al. (2017) menyatakan, bahwa siklon tropis Frances meningkatkan konsentrasi klorofil- $a$ di Laut Timor sebesar 0,4-5,0 mg/m disertai dengan penurunan SPL dengan nilai tertinggi mencapai 2,5 ${ }^{\circ} \mathrm{C}$ dalam kurun waktu 1-4 hari (Gambar 6).

Nilai koefisien $\mathrm{R}^{2}$ antara besarnya pengaruh SPL dan naik turunnya konsentrasi klorofil- $a$ mencapai 0,5109 (51\%). Nilai determinasi ini menunjukkan, salinitas memengaruhi konsentrasi 
klorofil-a cukup besar, yaitu sebesar $51 \%$. Sedangkan sisanya (49\%) dipengaruhi faktor lain. Hal tersebut sejalan dengan Gaol et al. (2018) (Gambar 7).

\section{KESIMPULAN}

Kecepatan angin, salinitas, dan klorofil- $a$ mengalami kenaikan pada saat terjadinya siklon tropis Amang, jika dibandingkan dengan sebelum dan setelah terjadinya siklon tersebut. Sedangkan SPL, mengalami penurunan. Hubungan antara kecepatan angin dan konsentrasi klorofil-a memiliki pengaruh yang paling besar $(r=0,76)$ dan kecepatan angin memengaruhi konsentrasi klorofil- $a$ sebesar $57 \%$. Hubungan antara SPL dan konsentrasi klorofil- $a$ menunjukkan nilai korelasi negatif kuat $(\mathrm{r}=-0,71)$ dan SPL memengaruhi konsentrasi klorofil-a sebesar $51 \%$. Hubungan antara salinitas dan konsentrasi klorofil- $a$ memiliki pengaruh yang rendah $(\mathrm{r}=0,45)$ dan salinitas memengaruhi nilai konsentrasi klorofil$a$ sebesar $20 \%$.

Ucapan terima kasih. Penulis mengucapkan terima kasih kepada semua pihak yang telah membantu dalam pelaksanaan penelitian dan penulisan naskah hasil penelitian ini untuk publikasi dalam jurnal ilmiah. Kami menyatakan bahwa tidak ada konflik kepentingan dengan organisasi manapun mengenai bahan yang didiskusikan dalam naskah ini. "Kami menyatakan bahwa tidak ada konflik kepentingan dengan organisasi manapun mengenai bahan yang didiskusikan dalam naskah ini".

\section{REFERENSI}

AYU, D.R.A., SUKOJO, B.M. and JAELANI, L.M. (2011) Studi perubahan suhu permukaan laut menggunakan satelit Aqua Modis. Geoid, 07 (01), pp. 073-078.

BERNAWIS, L.I. (2000) Temperature and pressure responses on El-Nino 1997 and La-Nina 1998 in
Lombok strait. Proceedings pf the JSPS-DGHE International Symposium on Fisheries Science in Tropical Area, Indonesia, Agustus 2000. pp. 6773.

GAOL, A.L., SIADARI, E.L., RYAN, M. and KRISTIANTO, A. (2018) Dampak siklon tropis frances terhadap upwelling laut Timor dan sekitarnya. Jurnal Meteorologi Klimatologi dan Geofisika, 5 (3), pp. 37-45.

GHOZALI, I. (2006) Aplikasi Analisis Multivariete dengan Program SPSS. Semarang: Badan Penerbit Universitas Diponegoro. 315 p.

HATTA, M. (2002) Hubungan antara klorofil-a dan ikan pelagis dengan kondisi oseanografi di perairan Utara Irian Jaya. Bogor: Institut Pertanian Bogor.

SIADARI, E.L., MANURUNG, R.M. and MUNANDAR, M.A. (2017) Dampak siklon tropis frances terhadap tingkat kesuburan perairan Laut Timor dan sekitarnya. Seminar Nasional Fisika dan Aplikasinya. pp. 1-6.

SUGIYONO. (2010) Metode Penelitian Kuantitatif, Kualitatif, dan $R \& D$. Bandung: Alfabeta.

TANGKE, U., KARUWAL, J.CH., ZAINUDDIN, M. and MALLAWA, A. (2015) Sebaran suhu permukaan laut dan klorofil-a pengaruhnya terhadap hasil tangkapan yellowfin tuna (Thunnus albacares) di perairan laut Halmahera bagian Selatan. Jurnal IPTEKS PSP, 2 (3), pp. 248-260.

WANG, G., LING, Z. and WANG, C. (2009) Influence of tropical cyclones on seasonal ocean circulation in the South China sea. Journal of Geophysical Research, 114 (C10), pp. 1-9.

YE, H.J., SUI, Y., TANG, D.L. and AFANASYEV, Y.D. (2013) A subsurface chlorophyll-a bloom induced by typhoon in the South China sea. Journal of Marine Systems, 128, pp. 138-145.

ZAKIR, A. and KHOTIMAH, M.K. (2006) Badai dan pengaruhnya terhadap cuaca buruk di Indonesia. Jakarta: BMKG.

ZAKIR, A., SULISTYA, W. and KHOTIMAH, M.K. (2010) Perspektif operasional cuaca tropis. Jakarta: BMKG. 